Research article

\title{
MINERAL SUPPLEMENTATION: EFFECTS ON BONE INTEGRITY AND INTESTINAL MORPHOMETRY OF BROILER CHICKENS CHALLENGED WITH EIMERIA SP
}

\author{
FERNANDES MÜLLER Inês Jovanir ${ }^{*}$, RIBEIRO VISSOTTOO Mayra ${ }^{1}$, \\ CARDOSO BITTENCOURT Letícia ${ }^{1}$, RIFFEL Thais Eliana ${ }^{1}$, LIMA KAISER \\ Fernanda ${ }^{1}$, PALMA CASTRO Sabrina ${ }^{1}$, HERMES Gustavo Rafael ${ }^{2}$
}

${ }^{1}$ Laboratory of Poultry Experimentation, Federal University of Parana, Palotina, Parana, Brazil; ${ }^{2}$ DSM Nutritional Products, São Paulo, Brazil

(Received 22 August 2018, Accepted 11 March 2019)

\begin{abstract}
The objective of this study was to evaluate the effect of supplementation of organic minerals on the productive performance and bone quality of broilers from 1 to 21 days of age and the intestinal health in situations of enteric challenge from 21 to 28 days of age. In a completely randomized design, with two treatments composed for minerals as sulfate and Carbo-Amino-Phospho-Chelate (CAPC), a total of 900 male broiler chicks were allocated to nine replicates and 18 experimental units with 50 birds each. 640 birds at 21 days of age were transferred to experimental cages and distributed in a completely randomized design, in factorial $2 \times 2$ (minerals as sulfate and CAPC x with and without enteric challenge), obtaining 4 treatments with 16 replicates and 10 birds each. In the same day of change, the group of challenged broilers received a commercial vaccine for coccidiosis that covers the Eimeria sp. At 7 days, the supplementation with CAPC minerals resulted in higher $(\mathrm{p}<0.05)$ weight gain and better feed conversion in relation to the inorganic source. The deposition of minerals evaluated in the tibia of broilers was not influenced $(\mathrm{p}>0.05)$ by the source of minerals, with the exception of $\mathrm{Cu}$ and $\mathrm{Mn}$, whose deposition was greater $(\mathrm{p}<0.05)$ in the bones of poultries supplemented with inorganic source of minerals. There was higher $(\mathrm{p}<0.05)$ length and width of the villi and increase in the ratio villus: crypt in response to the intestinal spoliation with CAPC supplementation when compared to the inorganic source.
\end{abstract}

Key words: organic minerals, intestinal challenge, renewal and cell proliferation, breaking bone resistance

\section{INTRODUCTION}

Genetic selection of broiler chickens includes multiple selection criteria for production characteristics related to the growth aiming at economic gains and compliance to the consumer's demands. The result is a body, that in about 60 years experienced a 300\%

*Corresponding author: e-mail: jovanirfernandes@gmail.com 
increase in the rate of growth [1] and changes in body conformation, mainly in the deposition of the pectoral muscle mass [2,3]. Despite the undeniable advances in the meat yield there has been an evolution in skeletal harmonic structure, which resulted in growing anomalies, which, in addition to economic losses, affected the poultries' well-being, since these are processes that involve pain and inflammation.

In this sense, the search for solutions to fit correctly the nutritional needs, especially of minerals for bone development, considering the rapid growth and the consequent reduction in the age of slaughter, is fundamental. The diets supplementation with organic minerals as a replacement for conventional inorganic ones is a tool which has been studied and used as the bond with an organic molecule offers greater stability and increased bioavailability [4,5]. Added to this, the increase of the safety margin in the micro mineral supplementation, in the form of nitrogen oxides or sulfates, results in a high level of mineral excretion [6], generating problems of environmental contamination [7].

Nollet et al. [8] reported a reduction in the excretion of manganese (Mn), zinc ( $\mathrm{Zn})$, iron $(\mathrm{Fe})$ and copper $(\mathrm{Cu})$ in the order of 46, 63, 73 and 55\% in comparison to the diet supplemented with inorganic minerals.

The availability of minerals is essential for the growth of modern broiler lineages on grounds of involvement in many physiological processes and biosynthesis, acting mainly as intracellular enzymatic catalysts or as constituents of enzymes. The minerals microelements are several proteins involved in intermediate metabolism, in pathways of hormone secretion and in the immune system [9].

$\mathrm{Mn}$ and $\mathrm{Zn}$ are co-factors involved in the synthesis of mucopolysaccharides and carbonates, which are essential for bone formation [10]. Due to their role in collagen crosslinking, the element $\mathrm{Cu}$ promotes greater resistance of the skin, bones, tendons and intestine [11]. Experiments with broilers have demonstrated a strong correlation between the bone resistance and the extension of the crosslinking of collagen [12]. In addition to these functions, $\mathrm{Zn}, \mathrm{Cu}$ and $\mathrm{Mn}$ are structural components and or catalytic of the antioxidant enzyme superoxide dismutase (SOD) and act on immunity mediators such as enzymes, the thymus peptides and cytokines [13]. Selenium (Se), in addition to acting in antioxidant defense systems, protecting the body from oxidative stress $[14,15]$, prevents the occurrence of diseases especially those that have oxidative stress as a triggering factor, in addition to the maintenance of the integrity of tissues.

The role of $\mathrm{Zn}$ in anti-inflammatory response and resistance to infection is well known [16,17], particularly in the resistance to intestinal diseases [18].

Intestinal health is defined in accordance with the physical and chemical components which constitute the intestinal barrier, as well as by its ability to selectively absorb the nutrients.

The animal's intestine role is to absorb nutrients and also to act as a barrier to prevent the transposition of pathogens and toxins [19]. The epithelial cells that cover the intestinal 
tract are connected by junctional complexes which consist of gap junctions, adherent junctions, desmosomes and tight junctions. The tight junctions play an important role, constituting the interconnections among the cells [20], by means of proteins, as claudin and occluding, which seal the spaces among the cells that comprise the epithelial layer, making it an impermeable barrier or selectively permeable for the transport of water and small molecules [21]. Hu et al. [17] demonstrated that $\mathrm{Zn}$ improved the intestinal permeability of broiler chickens and increased the length of the villus and the ratio villus: mucosa crypt of the duodenum. It is important to consider, that changes in intestinal morphology as the reduction of villi and greater crypt depth can result in poor nutrients absorption, increased intestinal secretion, diarrhea, reduced resistance to diseases and consequently worse productive performance.

The use of organic sources is still limited due to its relatively high cost, burdening the cost of the mineral fraction of the diets. However, these are products of high added value and inserted in a context of sustainability, important concepts, whereas the modern poultry industry has been increasingly committed to environmental issues and food security [11]. In addition, it is necessary to take into consideration that, with the poultries' continuous genetic evolution, it is essential to know not only the micro mineral nutritional requirements for the maximum productive performance, but also ensure that they are available to ensure the intestinal health and bone integrity.

The objective of this study was to evaluate the effect of supplementation of organic minerals on the productive performance and bone quality of broilers from 1 to 21 days of age and the intestinal health in situations of enteric challenge from 21 to 28 days of age.

\section{MATERIAL AND METHODS}

The experiment was carried out in the Experimental Poultry House of Federal University of Paraná - Palotina. All procedures for the raising of animals and biological material collection were approved by the Ethics Committee on Animal Use in experimentation under protocol no. 51/2014.

In a completely randomized design, with two treatments composed for minerals as sulfate or Carbo-Amino-Phospho-Chelate (CAPC), a total of 900 male broiler Cobb Slow chicks were allocated to nine replicates and 18 experimental units with 50 birds each.

Based on corn and soybean meal, the diets were formulated according to the ingredients chemical composition and the nutritional recommendations adopted by the local poultry integrations (Table 1). The CAPC and sulfate mineral premix were added according to the treatments and recommendations, $5 \mathrm{~kg} /$ ton (Table 2). 
Table 1. Nutritional composition of diets provided to the broilers

\begin{tabular}{|c|c|c|}
\hline Ingredients, \% & Starter & Grower \\
\hline Corn & 53.07 & 55.12 \\
\hline Soybean meal & 34.00 & 29.90 \\
\hline Meat meal & 5.20 & 4.50 \\
\hline Soybean oil & 4.10 & 5.50 \\
\hline Offal meal & 1.50 & 3.00 \\
\hline Limestone & 0.340 & 0.420 \\
\hline Salt & 0.310 & 0.310 \\
\hline Sodium bicarbonate & 0.103 & - \\
\hline Vitamin and mineral premix ${ }^{1}$ & 0.500 & 0.500 \\
\hline Choline $60 \%$ & 0.086 & 0.052 \\
\hline L-Lysine 70\% & 0.316 & 0.284 \\
\hline L-Threonine 98\% & 0.092 & 0.084 \\
\hline L-Valine & 0.021 & 0.012 \\
\hline \multicolumn{3}{|l|}{ Nutritional composition } \\
\hline Crude Protein, \% & 23.30 & 22.12 \\
\hline $\mathrm{ME}, \mathrm{Kcal} / \mathrm{kg}$ & 3100 & 3230 \\
\hline Crude Fat, \% & 7.16 & 8.69 \\
\hline Crude Fiber, $\%$ & 3.08 & 2.89 \\
\hline Calcium, \% & 1.03 & 1.02 \\
\hline Available P, \% & 0.46 & 0.45 \\
\hline Dig Lys, \% & 1.250 & 1.160 \\
\hline Dig AAS, $\%$ & 0.761 & 0.779 \\
\hline Dig Thr, \% & 0.813 & 0.766 \\
\hline Dig Trp, $\%$ & 0.225 & 0.209 \\
\hline Dig Leuc, \% & 1.670 & 1.599 \\
\hline Dig Ile, $\%$ & 0.692 & 0.698 \\
\hline Dig Val, \% & 0.963 & 0.905 \\
\hline Dig Arg, \% & 1.411 & 1.325 \\
\hline Choline, $\mathrm{mg} / \mathrm{kg}$ & 1850.87 & 1651.35 \\
\hline $\mathrm{Na}, \%$ & 0.212 & 0.176 \\
\hline $\mathrm{Cl}, \%$ & 0.273 & 0.260 \\
\hline $\mathrm{K}, \%$ & 0.900 & 0.826 \\
\hline $\mathrm{Na}+\mathrm{K}+\mathrm{Cl}, \mathrm{Meq} / 100 \mathrm{~g}$ & 246 & 215 \\
\hline
\end{tabular}

${ }^{1}$ Levels are described in Table 2 
Table 2. Vitamin and mineral programs per ton of feed

\begin{tabular}{lcccc}
\hline & Starter & Grower & Starter & Grower \\
\hline Trace minerals $(\mathbf{m g})$ & \multicolumn{1}{c}{ CAPC } & trace & minerals* & \multicolumn{2}{c}{ Inorganic } & trace & minerals** \\
\hline Manganese & 56 & 56 & 120 & 100 \\
Zinc & 44 & 44 & 100 & 80 \\
Iron & 44 & 44 & 70 & 60 \\
Copper & 8.6 & 8.6 & 8 & 8 \\
Selenium & 0.340 & 0.340 & 0.240 & 0.240 \\
Iodine & 1 & 1 & 1 & 1 \\
\hline
\end{tabular}

*CAPC trace minerals: copper carbo-amino-phospho-chelate, iron carbo-amino-phospho-chelate, manganese carbo-amino-phospho-chelate, selenium carbo-amino-phospho-chelate, zinc carbo-aminophospho-chelate, and calcium iodate.

**Inorganic trace minerals: iron sulfate, manganese sulfate, zinc sulfate, copper sulfate, sodium selenite and calcium iodate.

Vitamins in the starter: Vitamin A: 12,000 IU, Vitamin $\mathrm{D}_{3}$ 3,500 IU, Vitamin E: $30 \mathrm{mg}$, Vitamin K: 3mg, Vitamin B1: 3.0mg, Vitamin B2: $8.0 \mathrm{mg}$, Vitamin B6: 5.0mg, Vitamin B12: 0.020mg, Niacin:

40mg, Pantothenic acid: $18 \mathrm{mg}$, Folic acid: $2.5 \mathrm{mg}$, Biotin: $0.24 \mathrm{mg}$

Vitamins in the grower: Vitamin A: 9,000 IU, Vitamin $\mathrm{D}_{3} 3,0 \mathrm{IU}$, Vitamin E: $25 \mathrm{mg}$, Vitamin K: 3mg, Vitamin B1: 2.4mg, Vitamin B2: $6.5 \mathrm{mg}$, Vitamin B6: 4.2mg, Vitamin B12: 0.015mg, Niacin: $35 \mathrm{~m} \mathrm{~g}$, Pantothenic acid: $15 \mathrm{mg}$, Folic acid: $1.5 \mathrm{mg}$, Biotin: $0.21 \mathrm{mg}$

The birds were housed in an environmentally controlled poultry barn (exhaustion system, evaporative pads and electrical brooders), divided into 36 pens $\left(3.52 \mathrm{~m}^{2}\right)$, with reused wood shavings ( $6^{\text {th }}$ flock) covering the floor. The thermal comfort temperature was maintained according to age. Birds had 24 hours of light until day 14 , due to the heating system ( $300 \mathrm{~W}$ halogen lamp), and 16 hours of light and 8 hours of dark from then on.

The birds were weighed every week, as well as the leftover feed, to provide the information to evaluate average weight, weight gain, average daily gain, feed intake, and feed conversion. Feed conversion was corrected by the weekly mortality according to the method described by Sakomura and Rostagno [22]. The daily mortality records were also used to calculate the viability.

At 21 days, the birds were euthanized by cervical dislocation (36 birds per treatment), in accordance with legal slaughter methods and as prescribed by a resolution from the Animal Wellbeing and Ethics Committee.

The left tibiotarsus was removed, weighted and the diameter and length were measured with the aid of a digital paquimeter $(\mathrm{mm})$. The tibiotarsus for each birds was then subjected to bending test (breaking bone resistance) at constant strain rate for visco-elastic material with the aim of a CT3 Texture Analyzer (Brookfield AMETEK Inc., Massachusetts, USA). Then, the same bones were subjected to fat extraction by successive treatment in petroleum ether for 8 hours, then dried for 12 hours in an oven, weighted and calcined in a muffle furnace at $540^{\circ} \mathrm{C}$ for $6 \mathrm{~h}$ for determination 
of bone ash. Bone ash (1 gram per bone) was dissolved in $50 \% \mathrm{HNO}_{3}$ and submitted to digestion. Afterwards, $2 \% \mathrm{HNO}_{3}$ was added to the solution that was weighted to obtain the dilution factor. The mineral extract was carefully filtered through Whatman ${ }^{\circledR}$ Grade 42 filter paper (Whatman International Ltd., Maidstone, England) and the filtrates were used to analyze $\mathrm{Ca}, \mathrm{P}, \mathrm{Cu}, \mathrm{Fe}, \mathrm{Mn}$ and $\mathrm{Zn}$ concentrations through flame atomic absorption spectrophotometry on a Solaar Spectrometer, Thermo Fisher Scientific.

A total of 640 birds at 21 days of age of similar weight were selected from respective treatment and transferred to experimental cages and distributed in a completely randomized design, in factorial $2 \times 2$ (minerals as sulfate and CAPC $\mathrm{x}$ with and without enteric challenge), obtaining 4 treatments with 16 replicates and 10 birds each. In the same day of change, the group of challenged broilers received a commercial vaccine for coccidiosis that covers the species E. acervulina, E. maxima, E. praecox, E. tenella, and E. mitis. Prior to the application of the vaccine, the sporulation of oocytes was performed by injection of $\mathrm{O}_{2}$ directly into Falcon tubes with the vaccine, which were quickly sealed and maintained in a BOD oven at $82,4^{\circ} \mathrm{F}$ for 48 hours. The vaccine was inoculated directly into the gizzard of each broiler at 20 times the dose recommended by the manufacturer ( $\pm 80,000$ oocytes). In this phase ( 22 to 28 days), the birds received only grower feed (Table 1).

At the age of 28 days, two birds per pen ( 32 birds/ treatment) were randomly selected and euthanized by cervical dislocation in accordance with legal slaughter methods and as prescribed by a resolution from the Animal Wellbeing and Ethics Committee. After this procedure, the small intestine was removed, and samples of the segments of the duodenum, jejunum and ileum were collected and fixed in buffered formaldehyde and embedded in paraffin to obtain semi-serial cross-sections $5 \mu \mathrm{m}$ of thickness and stained with hematoxylin-eosin. For morphometric study, digital images were obtained by light microscopy (Olympus BX 50), using a computerized image analyzer system (Image Pro-Plus - Version 5.2 - Cybernetics Mean). In this study, the length and width of 20 villi and the depth and width of 20 crypts of each section were measured. These morphometric measures were also utilized for the calculation of the area of intestinal mucosa absorption surface, through the formula proposed by Kisielinski et al. [23]: Absorption area: ((WV x HV) + (WV/2+WC/2) $\left.-(\mathrm{WV} / 2)^{2}\right) /\left((\mathrm{WV} / 2+\mathrm{WC} / 2)^{2}\right)$, where: WV is the width of the villus, $\mathrm{HV}$ is the height of the villus, and $\mathrm{WC}$ is the width of the crypt.

The statistical analysis of data was carried out through the procedure GLM of SAS [24]. Prior to the analysis of variance, all variables were tested as for normality. Variables analyzed presented normal distribution, and thus data were subjected to parametric tests. 


\section{RESULTS}

There was a significant effect $(\mathrm{p}<0.05)$ of treatments on average weight and weight gain at 7 and 14 days of age (Table 3). The supplementation with CAPC minerals resulted in higher average weight and weight gain in relation to the inorganic source. At 7 days, there was statistical difference $(p<0.05)$ for feed conversion, birds that received diets with CAPC minerals showed better feed conversion in relation to the birds which received diets with the inorganic source. However, at 21 days of age, no significant difference was observed between the treatments (Table 3).

Table 3. Performance of broilers fed different mineral sources in the initial phase ( 1 to 21 days $)^{1}$

\begin{tabular}{|c|c|c|c|c|}
\hline & Live weight, $\mathrm{g}$ & Weight gain, $\mathrm{g}$ & Feed intake, $g$ & Feed Conversion \\
\hline \multicolumn{5}{|c|}{ 1-7 days } \\
\hline \multicolumn{5}{|c|}{ Source trace minerals } \\
\hline Inorganic & $164.95^{\mathrm{b}}$ & $117.22^{\mathrm{b}}$ & 143.53 & $1.225^{\mathrm{a}}$ \\
\hline CAPC & $173.74^{\mathrm{a}}$ & $126.04^{\mathrm{a}}$ & 145.61 & $1.159^{\mathrm{b}}$ \\
\hline $\mathrm{CV}, \%$ & 3.57 & 5.06 & 2.15 & 5.16 \\
\hline Value of $\mathrm{P}$ & 0.0069 & 0.0079 & 0.1749 & 0.0361 \\
\hline \multicolumn{5}{|c|}{ 1-14 days } \\
\hline Inorganic & $497.39^{\mathrm{b}}$ & $448.62^{\mathrm{b}}$ & 582.59 & 1.299 \\
\hline CAPC & $517.42^{\mathrm{a}}$ & $473.19^{\mathrm{a}}$ & 596.94 & 1.263 \\
\hline $\mathrm{CV}, \%$ & 2.92 & 3.64 & 3.09 & 4.04 \\
\hline Value of $\mathrm{P}$ & 0.0138 & 0.0068 & 0.1142 & 0.1626 \\
\hline \multicolumn{5}{|c|}{ 1-21 days } \\
\hline Inorganic & 943.49 & 892.68 & 1209.14 & 1.356 \\
\hline CAPC & 945.02 & 895.64 & 1230.29 & 1.375 \\
\hline $\mathrm{CV}, \%$ & 2.8931 & 3.16 & 1.78 & 3.17 \\
\hline Value of $\mathrm{P}$ & 0.9071 & 0.8273 & 0.0558 & 0.3749 \\
\hline
\end{tabular}

${ }^{1}$ Values are the mean of 450 birds/treatment. CV: coefficient of variation

Different lowercase letters in the same column differ $(\mathrm{P}<0.05)$.

The deposition of minerals evaluated in the tibia of broilers (Table 4) was not influenced by the sources of minerals, with the exception of $\mathrm{Cu}$ and $\mathrm{Mn}$, whose deposition was greater in the bones of poultries supplemented with the inorganic source of minerals. Despite this greater deposition of minerals involved in the collagen formation, no significant differences were observed $(\mathrm{p}>0.05)$ in weight, length, diameter and bone resistance to fractures (Table 5). 
Table 4. Deposition of minerals in the tibiotarsus in 21 days old broilers fed different mineral sources in the initial phase (1 to 21 days) ${ }^{1}$

\begin{tabular}{lccccccc}
\hline & $\begin{array}{c}\mathbf{A s h} \\
\mathbf{0}\end{array}$ & $\begin{array}{c}\mathbf{C a} \\
\mathbf{\%}\end{array}$ & $\begin{array}{c}\mathbf{P} \\
\mathbf{\%}\end{array}$ & $\begin{array}{c}\mathbf{C u} \\
\mathbf{m g} / \mathbf{k g}\end{array}$ & $\begin{array}{c}\mathbf{F e} \\
\mathbf{m g} / \mathbf{k g}\end{array}$ & $\begin{array}{c}\mathbf{M n} \\
\mathbf{m g} / \mathbf{k g}\end{array}$ & $\begin{array}{c}\mathbf{Z n} \\
\mathbf{m g} / \mathbf{k g}\end{array}$ \\
\cline { 2 - 8 } Source trace minerals & & & & & & & \\
Inorganic & 36.66 & 14.66 & 7.59 & $5.82^{\mathrm{a}}$ & 79.16 & $2.77^{\mathrm{a}}$ & 122.54 \\
CAPC & 36.48 & 14.01 & 7.10 & $4.22^{\mathrm{b}}$ & 76.02 & $2.11^{\mathrm{b}}$ & 126.51 \\
$\mathrm{CV}, \%$ & 4.80 & 6.71 & 6.25 & 4.80 & 6.82 & 14.80 & 6.82 \\
\hline Value of P & 0.7465 & 0.2814 & 0.0893 & 0.0055 & 0.2848 & 0.0001 & 0.1478 \\
\hline
\end{tabular}

${ }^{1}$ Values are the mean of 36 birds/treatment. CV: coefficient of variation

Table 5. Bone measurements of the tibia for 21 days old broilers fed different mineral sources in the initial phase (1 to 21 days $)^{1}$

\begin{tabular}{lcccc}
\hline & Weight, $\mathbf{g}$ & Length, $\mathbf{m m}$ & Diameter, $\mathbf{m m}$ & Strength, $\mathbf{k g}$ \\
\hline Source trace minerals & & & & \\
Inorganic & 8.93 & 78.41 & 5.94 & 19.05 \\
CAPC & 8.75 & 77.22 & 5.84 & 19.60 \\
CV, \% & 9.93 & 3.11 & 8.21 & 17.25 \\
Value of P & 0.5186 & 0.1298 & 0.5173 & 0.6061 \\
\hline
\end{tabular}

${ }^{1}$ Values are the mean of 36 birds/treatment. CV: coefficient of variation

The results regarding the productive performance from 21 to 28 days of age, when the broilers were subjected or not to the enteric challenge are shown in Table 6 . There was no significant effect $(\mathrm{p}>0.05)$ of the mineral source regardless of the enteric challenge. Despite this, the enteric challenge with inoculation of Eimeria sp in poultries' crops, resulted in a change of histomorphometry of the intestinal mucosa of the three segments (duodenum, jejunum and ileum) evaluated (Tables 7 to 12).

Table 6. Performance for 21 to 28 days old broilers fed different mineral sources and submitted or not to experimental enteric challenge ${ }^{1}$

\begin{tabular}{lcccc}
\hline & Live weight, $\mathbf{g}$ & Weight gain, $\mathbf{g}$ & Feed intake, $\mathbf{g}$ & Feed Conversion \\
\hline Source trace minerals & & & & \\
Inorganic & 1512.81 & 561.00 & 859.33 & 1.510 \\
CAPC & 1502.91 & 553.25 & 836.29 & 1.479 \\
Enteric challenge & & & & \\
Control & 1507.31 & 545.93 & 837.95 & 1.508 \\
Challenged & 1508.41 & 568.31 & 857.66 & 1.482 \\
CV, \% & 4.92 & 12.19 & 6.91 & 6.85 \\
Minerals & 0.5956 & 0.6497 & 0.1207 & 0.2560 \\
Challenge & 0.9532 & 0.1926 & 0.1832 & 0.3540 \\
M x C & 0.2016 & 0.7967 & 0.6272 & 0.5789 \\
\hline
\end{tabular}

${ }^{1}$ Values are the mean of 160 birds/treatment. CV: coefficient of variation 
In the evaluation of the mucosa of the duodenum (Table 7), significant interaction was observed for length and width of the villus and crypt depth. In the unfolding of the interaction (Table 8), it can be seen that the enteric challenge in birds supplemented with the inorganic source reduced $(\mathrm{p}<0.05)$ the villus length, while the replacement by organic CAPC source maintained the same villus length as that observed for the control animals. For animals that were not subjected to the challenge, the villus length did not have any change in function of the source. For the unfolding of the width data of the villus, it was observed that the inclusion of CAPC minerals in situations of intestinal challenge led to an increase $(\mathrm{p}<0.05)$ of the villus width when compared to control poultries. On the other hand, considering the control poultries, there was greater $(\mathrm{p}<0.05)$ width of the villus when used inorganic source of minerals. These results are correlated to data obtained for the crypt depth. Control poultries that showed greater villus width, also presented a greater crypt depth, indicating a greater need for cell proliferation. This behavior is observed with the supplementation of source of CAPC minerals, i.e., in a situation of challenge, there was an increase of the proliferative capacity of the crypt that resulted in higher $(p<0.05)$ length and width of the villus in response to the intestinal spoliation when compared to the inorganic source.

The supplementation of CAPC source, regardless of the enteric challenge also resulted in higher $(\mathrm{p}<0.05)$ ratio villus: crypt and larger absorption area in comparison with the inorganic source (Table 7). The enteric challenge, regardless of the source of mineral used resulted in a greater ratio villus: crypt. This result shows that for both factors, mineral supplementation and challenge, there was an increase in the ratio villus: crypt, however, only for the factor mineral supplementation with CAPC source this increase of the ratio was a consequence of the villus increase.

Table 7. Intestinal mucosa morphology of the duodenum in 28 days old broilers fed different mineral sources and submitted or not to experimental enteric challenge ${ }^{1}$

\begin{tabular}{|c|c|c|c|c|c|c|}
\hline & $\begin{array}{c}\text { Villus } \\
\text { length, } \mu \mathrm{m}\end{array}$ & $\begin{array}{c}\text { Villus width, } \\
\mu \mathrm{m}\end{array}$ & $\begin{array}{c}\text { Crypt depth, } \\
\mu \mathrm{m}\end{array}$ & VL:CD* & $\mathrm{CN}: \mathrm{VN} * *$ & $\begin{array}{c}\text { Absorptive } \\
\text { area, } \mu \mathrm{m} 2\end{array}$ \\
\hline \multicolumn{7}{|c|}{ Source trace minerals } \\
\hline Inorganic & 890.07 & 59.07 & 113.34 & $7.93^{\mathrm{b}}$ & 3.84 & $11.62^{\mathrm{b}}$ \\
\hline CAPC & 1031.40 & 54.99 & 104.70 & $9.96^{\mathrm{a}}$ & 4.39 & $15.23^{\mathrm{a}}$ \\
\hline \multicolumn{7}{|c|}{ Enteric challenge } \\
\hline Control & 1003.01 & 54.63 & 107.17 & $9.57^{\mathrm{a}}$ & 3.85 & 14.03 \\
\hline Challenged & 901.31 & 59.56 & 111.62 & $8.26^{\mathrm{b}}$ & 4.37 & 12.71 \\
\hline $\mathrm{CV}, \%$ & 25.35 & 23.42 & 25.45 & 22.96 & 44.39 & 22.75 \\
\hline Minerals & 0.0243 & 0.2343 & 0.3051 & 0.0002 & 0.2341 & 0.0001 \\
\hline Challenge & 0.2160 & 0.1208 & 0.4900 & 0.0139 & 0.2483 & 0.0840 \\
\hline $\mathrm{M} \times \mathrm{C}$ & 0.0133 & 0.0003 & 0.0252 & 0.4922 & 0.7270 & 0.7147 \\
\hline
\end{tabular}

${ }^{1}$ Values are the mean of 32 birds/treatment. CV: coefficient of variation

Different lowercase letters in the same column differ $(\mathrm{P}<0.05)$

*VL:CD: villus length: crypt depth ratio, ${ }^{* *} \mathrm{CN}: \mathrm{VN}$ : crypt number: villus number ratio 
Table 8. Unfolded interaction of villus length, villus width and crypt depth for 28 days old broilers in the duodenum ${ }^{1}$

\begin{tabular}{lccc}
\hline & Control & Challenged & Value of P \\
\hline & \multicolumn{3}{c}{ Villus length, $\mu \mathrm{m}$} \\
\cline { 2 - 4 } Source trace minerals & $1010.90^{\mathrm{aA}}$ & $769.23^{\mathrm{bB}}$ & 0.0144 \\
Inorganic & $994.58^{\mathrm{aA}}$ & $1077.42^{\mathrm{aA}}$ & 0.3267 \\
CAPC & 0.8537 & 0.0024 & \\
Value of P & \multicolumn{3}{c}{ Villus width, $\boldsymbol{\mu m}$} \\
\cline { 2 - 4 } & $62.95^{\mathrm{aA}}$ & $55.19^{\mathrm{aA}}$ & 0.1588 \\
Source trace minerals & $45.75^{\mathrm{bB}}$ & $64.22^{\mathrm{aA}}$ & 0.0001 \\
Inorganic & 0.0010 & 0.0767 & \\
CAPC & & Crypt depth, $\mu \mathrm{m}$ & \\
Value of P & & & 0.2907 \\
\cline { 2 - 4 } & $119.44^{\mathrm{aA}}$ & $107.63^{\mathrm{aA}}$ & 0.0273 \\
\hline Source trace minerals & $94.90^{\mathrm{bB}}$ & $116.94^{\mathrm{aA}}$ & \\
\hline Inorganic & 0.0096 & 0.4427 & \\
\hline CAPC & & & \\
Value of P & & & \\
\hline
\end{tabular}

${ }^{1}$ Values are the mean of 32 birds/treatment

Different lowercase letters in the same line and different capital letters in the same column differ $(\mathrm{P}<0.05)$

Table 9. Intestinal mucosa morphology of the jejunum in 28 days old broilers fed different mineral sources and submitted or not to experimental enteric challenge ${ }^{1}$

\begin{tabular}{|c|c|c|c|c|c|c|}
\hline & $\begin{array}{c}\text { Villus } \\
\text { length, } \mu \mathrm{m}\end{array}$ & $\begin{array}{c}\text { Villus } \\
\text { width, } \mu \mathrm{m}\end{array}$ & $\begin{array}{c}\text { Crypt } \\
\text { depth, } \mu \mathrm{m}\end{array}$ & VL:CD* & $\mathrm{CN}: \mathrm{VN} * *$ & $\begin{array}{c}\text { Absorptive } \\
\text { area, } \mu \mathrm{m}^{2}\end{array}$ \\
\hline \multicolumn{7}{|c|}{ Source trace minerals } \\
\hline Inorganic & 963.12 & 162.67 & 102.32 & 9.62 & 1.84 & 12.73 \\
\hline CAPC & 946.52 & 163.23 & 100.75 & 9.57 & 1.87 & 11.93 \\
\hline \multicolumn{7}{|c|}{ Enteric challenge } \\
\hline Control & $885.11^{b}$ & $148.81^{b}$ & $92.68^{\mathrm{b}}$ & 9.78 & 1.87 & 11.99 \\
\hline Challenged & $1024.53^{\mathrm{a}}$ & $177.08^{\mathrm{a}}$ & $110.39^{\mathrm{a}}$ & 9.42 & 1.84 & 12.68 \\
\hline $\mathrm{CV}, \%$ & 22.26 & 27.18 & 19.13 & 23.83 & 23.70 & 24.04 \\
\hline Minerals & 0.7559 & 0.9596 & 0.7475 & 0.9339 & 0.8034 & 0.3110 \\
\hline Challenge & 0.0110 & 0.0133 & 0.0006 & 0.5254 & 0.8248 & 0.3534 \\
\hline $\mathrm{Mx} C$ & 0.5435 & 0.1973 & 0.4795 & 0.9560 & 0.0154 & 0.0632 \\
\hline
\end{tabular}

${ }^{1}$ Values are the mean of 32 birds/treatment. CV: coefficient of variation

Different lowercase letters in the same column differ $(\mathrm{P}<0.05)$.

*VL:CD: villus length: crypt depth ratio, ${ }^{* *} \mathrm{CN}: \mathrm{VN}$ : crypt number: villus number ratio 
In the evaluation of the mucosa of the jejunum (Table 9), it was observed that regardless of the mineral source, the enteric challenge led to an increase $(p<0.05)$ of the length and width of the villus and crypt depth. For the number of crypts in relation to villi, there was a significant interaction $(\mathrm{p}<0.05)$ between the mineral source and the enteric challenge. In the unfolding of the data, it was observed a higher number of crypts in relation to villi when the birds were supplemented with CAPC minerals and subjected to the enteric challenge (Table 10).

Table 10. Unfolded interaction of crypt number: villus number ratio for 28 days old broilers in jejunum ${ }^{1}$

\begin{tabular}{lccc}
\hline & Control & Challenged & Value of $\mathbf{P}$ \\
\cline { 2 - 4 } & \multicolumn{2}{c}{ Crypt number : Villus number ratio } \\
\cline { 2 - 4 } Source trace minerals & & & \\
Inorganic & $1.71^{\mathrm{aA}}$ & $1.97^{\mathrm{aA}}$ & 0.1465 \\
CAPC & $2.02^{\mathrm{aA}}$ & $1.72^{\mathrm{a}}$ & 0.0457 \\
Value of $\mathrm{P}$ & 0.0581 & 0.1282 & \\
\hline
\end{tabular}

${ }^{1}$ Values are the mean of 32 birds/treatment

Different lowercase letters in the same line and different capital letters in the same column differ $(\mathrm{P}<0.05)$

The data regarding the morphometry of the mucosa of the ileum are shown in (Table 11). The challenged poultries, regardless of the use of the mineral source presented a higher $(p<0.05)$ villus length of the ileum mucosa, as well as observed for the jejunum mucosa, which demonstrates that the enteric challenge, after a week, resulted in regenerative responses. In addition to this result, there was a significant interaction $(\mathrm{p}<0.05)$ between mineral sources and enteric challenge to the villus width, ratio villus: crypt and absorption area. In the unfolding of interactions (Table 12), there was only effect of inorganic source of minerals. The enteric challenge led to lower $(p<0.05)$ villi width, greater $(\mathrm{p}<0.05)$ ratio villus: crypt and higher $(\mathrm{p}<0.05)$ absorption area in poultries supplemented with inorganic source. However, for the absorption area, it was also observed that the inorganic source resulted in higher area $(p<0.05)$ when compared with the supplementation of chelated source. 
Table 11. Intestinal mucosa morphology in the ileum for 28 days old broilers fed different mineral sources and submitted or not to experimental enteric challenge ${ }^{1}$

\begin{tabular}{|c|c|c|c|c|c|c|}
\hline & $\begin{array}{c}\text { Villus length, } \\
\mu \mathrm{m}\end{array}$ & $\begin{array}{c}\text { Villus } \\
\text { width, } \mu \mathrm{m}\end{array}$ & $\underset{\mu \mathrm{m}}{\text { Crypt depth, }}$ & VL:CD* & $\mathrm{CN}: \mathrm{VN} * *$ & $\begin{array}{l}\text { Absorptive } \\
\text { area, } \mu \mathrm{m}^{2}\end{array}$ \\
\hline \multicolumn{7}{|c|}{ Source trace minerals } \\
\hline Inorganic & 472.05 & 189.45 & 99.98 & 4.77 & 1.77 & 6.83 \\
\hline CAPC & 444.03 & 189.51 & 96.16 & 4.76 & 1.79 & 6.14 \\
\hline \multicolumn{7}{|c|}{ Enteric challenge } \\
\hline Control & $428.54^{\mathrm{b}}$ & 192.41 & 94.63 & 4.69 & 1.85 & 6.02 \\
\hline Challenged & $487.06^{\mathrm{a}}$ & 186.55 & 101.46 & 4.84 & 1.72 & 6.95 \\
\hline $\mathrm{CV}, \%$ & 23.98 & 17.28 & 23.72 & 19.90 & 17.76 & 24.85 \\
\hline Minerals & 0.3071 & 0.9952 & 0.4933 & 0.9902 & 0.8547 & 0.0933 \\
\hline Challenge & 0.0388 & 0.5325 & 0.2376 & 0.5737 & 0.1119 & 0.0254 \\
\hline $\mathrm{M} \times \mathrm{C}$ & 0.3462 & 0.0202 & 0.2854 & 0.0150 & 0.3988 & 0.0410 \\
\hline
\end{tabular}

${ }^{1}$ Values are the mean of 32 birds/treatment. CV: coefficient of variation

Different lowercase letters in the same column differ $(\mathrm{P}<0.05)$.

* VL:CD: villus length:crypt depth ratio, ${ }^{* *} \mathrm{CN}: \mathrm{VN}$ : crypt number:villus number ratio

Table 12. Unfolded interaction of villus width, villus length:crypt depth ratio and absorptive area for 28 days old broilers in the ileum ${ }^{1}$

\begin{tabular}{|c|c|c|c|}
\hline & Control & Challenged & Value of $\mathbf{P}$ \\
\hline & \multicolumn{3}{|c|}{ Villus width, $\mu \mathrm{m}$} \\
\hline \multicolumn{4}{|l|}{ Source trace minerals } \\
\hline Inorganic & $202,00^{\mathrm{aA}}$ & $176,91^{\mathrm{aB}}$ & 0,0408 \\
\hline CAPC & $182,18^{\mathrm{aA}}$ & $196,83^{\text {aA }}$ & 0,2241 \\
\hline \multirow[t]{2}{*}{ Value of $\mathrm{P}$} & 0,1298 & 0,0739 & \\
\hline & \multicolumn{3}{|c|}{ Villus length: Crypt depth ratio } \\
\hline \multicolumn{4}{|l|}{ Source trace minerals } \\
\hline Inorganic & $4,40^{\mathrm{aB}}$ & $5,14^{\mathrm{aA}}$ & 0,0222 \\
\hline CAPC & $5,00^{\mathrm{aA}}$ & $4,54^{\text {aA }}$ & 0,2206 \\
\hline \multirow[t]{2}{*}{ Value of $\mathrm{P}$} & 0,1114 & 0,0638 & \\
\hline & \multicolumn{3}{|c|}{ Absorptive area, $\mu \mathrm{m}^{2}$} \\
\hline \multicolumn{4}{|l|}{ Source trace minerals } \\
\hline Inorganic & $5.94^{\mathrm{aB}}$ & $7.72^{\mathrm{aA}}$ & 0.0067 \\
\hline CAPC & $6.10^{\mathrm{aA}}$ & $6.18^{\mathrm{bA}}$ & 0.8777 \\
\hline Value of $\mathrm{P}$ & 0.7560 & 0.0221 & \\
\hline
\end{tabular}

${ }^{1}$ Values are the mean of 32 birds/treatment

Different lowercase letters in the same line and different capital letters in the same column differ $(\mathrm{P}<0.05)$ 


\section{DISCUSSION}

The results of the literature regarding the performance of broilers supplemented with chelated or inorganic sources are inconsistent [25-29]. In experimental conditions, the source of minerals used may not affect the productive performance of broiler chickens. Considering the high breeding density, the ambience conditions and, therefore, the greatest challenges to which the raised under commercial conditions are exposed continuously, it is possible that the mineral requirements may be higher. It is important to emphasize that the use of the chelated source allowed to decrease in almost $50 \%$ the inclusion of minerals as for instance the $\mathrm{Zn}, \mathrm{Fe}$ and $\mathrm{Mn}$, due to higher bioavailability and therefore reduction in the content of minerals in the poultries' excreta $[27,10]$.

The deposition of minerals evaluated in the tibia of broilers (Table 4) was not influenced by the sources of minerals. Considering that there were no differences on the performance of broiler chickens at 21 days of age and that the bones supporting the musculature, and growth and development are closely linked to the overall growth of the body [30], this result is consistent. Bao et al. [31] observed that, regardless of the contents of $\mathrm{Zn}$ in the tibia, supplementation in the diet of broilers with $\mathrm{Zn}$ alone or in combination with $\mathrm{Cu}, \mathrm{Fe}$ and $\mathrm{Zn}$ increased the content of these three minerals in the broilers tibia. These authors suggest that it is necessary to identify the first limiting mineral and the interaction among $\mathrm{Cu}, \mathrm{Fe}, \mathrm{Mn}$ and $\mathrm{Zn}$.

The same way, Gheisari et al. [32], did not observe any effect on the parameters of the tibia bone mineralization when inorganic minerals in the form of oxides of $\mathrm{Zn}, \mathrm{Mn}$ and $\mathrm{Cu}$, used in levels 100, 100 and 10 ppm, respectively, were replaced with amino acid chelates. Bao et al. [33] showed that the supplementation with $4 \mathrm{ppm} \mathrm{Cu}$ and 40 ppm each of Fe, $\mathrm{Mn}$ and $\mathrm{Zn}$ from organic complexes may be sufficient for normal broiler growth up to 29 days of age. These authors, encourage the use of lower levels of microelements in organic form in broiler chicken diets, which in addition to not interfering negatively with the poultry's growth, prevents excessive excretion of minerals.

In contrast to inorganic forms, organics forms are hardly soluble at neutral $\mathrm{pH}$, which provides increased trace mineral stability in the intestine. Less-reactive trace element ions occur in the upper digestive tract and are associated with fewer interactions with other feed components. The trace elements are released slowly over the full length of the small intestine resulting in improved trace element absorption and enhanced effects on intestinal health. The trace elements deficiency weakens the integrity of the intestinal lining and makes the gastrointestinal tract prone to inflammatory cell infiltration [18].

In spite of the productive performance from 21 to 28 days of age has not been changed, the enteric challenge, resulted in a change of histomorphometry of the intestinal mucosa of the three segments (duodenum, jejunum and ileum). In the evaluation 
of the mucosa of the duodenum was observed that in a situation of challenge, the supplementation of CAPC minerals increased the proliferative capacity of the crypt that resulted in higher length and width of the villus in response to the intestinal spoliation when compared to the inorganic source. Moreover, was an increase in the ratio villus: crypt with CAPC supplementation that indicates a proper balance between the renewal and cell proliferation [34], better state of intestinal health [35] and better absorption of nutrients due to lower energy loss with cell renewal.

The ration villus: crypt is considered the most important parameter to evaluate the health and intestinal recovery [36]. Thus, the high ratio indicates a long villus that in combination with a shallow crypt, indicates constant cell renewal, which would correspond to a greater capacity for digestion and absorption of nutrients [37].

In the jejunum, the enteric challenge led to increase of the length and width of the villus and crypt depth. This change suggests an intense cell proliferation in an attempt to repair after a cellular spoliation, however, these situations may result in the appearance of "immature enterocytes" that have low absorption capacity, as well as decreased activity of enzymes at the brush border [38]. In this sense, longer villi may not have a direct correlation with the absorption capacity, since the enterocytes need to be mature enough and functionally active.

It is important to consider that the increase of the crypt depth soon after the infection aims at the rapid regeneration and proliferation of goblet cells producing mucus. With the depletion of the infection, it is necessary the proliferation of new cells absorptive to maintain the numerous functional activities of intestinal mucosa, for the restitution of the pool of cells used [39]. Thus, progenitor cells located at the base of the crypt differed in enterocytes in detriment to the goblet cells, since there are no more invaders present and there are good health and nutritional conditions, after the process of "maturation" of the enterocytes, there might be a compensatory gain resulting in larger villa, as for instance observed in this work.

In experimental conditions, this compensatory gain can be observed, however, in terms of commercial flocks, environmental, immunological challenges and management are more intense and frequent allowing after an episode as of coccidiosis, some pathogenic agents in due time establish themselves and generate gastrointestinal diseases determining important economic losses [40].

In this study using supplementation of inorganic or organic minerals in situations of enteric challenge we find the diet supplementation with the source of CAPC minerals resulted in greater weight and weight gain until 14 days of age, and better feed conversion at the end of the first week. Despite the reduction of the level of chelated minerals, the source has not interfered in bone development of broiler chickens at 21 days of age. We have obtained interesting results in relation to the supplementation of diets with the source of CAPC minerals on the regeneration of intestinal mucosa in conditions of enteric challenge. The obtained results indicate that the use of mineral 
sources of higher bioavailability can reduce mineral excretion in the feces, and thus reduce the potential harmful effects of poultry production on the environment.

\section{Authors' contributions:}

All authors equally participated in writing the paper and have approved the final version of the manuscript.

\section{Declaration of conflicting interests:}

The author(s) declared no potential conflicts of interest with respect to the research, authorship, and/or publication of this article.

\section{REFERENCES}

1. Knowles TG: Open Research Computation: Leg disorders in broiler chickens: prevalence, risk factors and prevention. [http://journals.plos.org/plosone/article?id=10.1371/journal. pone.0001545]

2. Lilburn MS: Skeletal growth of commercial poultry species. Poult Sci 1994, 73:897-903.

3. Schmidt CJ, Persia ME, Feierstein E, Kingham B, Saylor WW: Comparison of a modern broiler line and a heritage line unselected since the 1950s. Poult Sci 2009, 88:2610-2619

4. Vieira S: Chelated minerals for poultry. Braz J Poult Sci 2008, 10:73-79.

5. Rostagno HS, Albino LFT, Hannas MI, Donzele JL, Sakomura NK, Perazzo FG, Saraiva A, Teixeira MV, Rodrigues PB, Oliveira RF, Barreto SLT, Brito CO. In: Tabelas brasileiras para aves e suínos: composição de alimentos e exigências nutricionais. Viçosa, MG: Departamento de Zootecnia, Universidade Federal de Viçosa; 2017, 488.

6. Leeson S: Trace mineral requirements of poultry — validity of the NRC recommendations. In: Redefining Mineral Nutrition. Nottingham, United Kington: Nottingham University Press, 2005, 107-118.

7. Aksu T, Aksu M, Yoruk M, Karaoglu M: Effects of organically-complexed minerals on meat quality in chickens. Br Poult Sci 2011, 52:558-563.

8. Nollet L, Van Der Klis JD, Lensing M, Spring P: The effect of replacing inorganic with organic trace minerals in broiler diets on productive performance and mineral excretion. J Appl Poult Res 2007, 16:592-597.

9. Dieck HT, Doring F, Roth HP: Changes in rat hepatic gene expression in response to zinc deficiency as assessed by DNA arrays. J Nutr 2003, 133:1004-1010.

10. Światkiewicz S, Arczewska-Włosek A, Jozefiak D: The efficacy of organic minerals in poultry nutrition: review and implications of recent studies. Worlds Poult Sci J 2014, 70:475-486.

11. Richards JD, Zhao J, Harreil RJ, Atwell C, Dibner JJ: Trace mineral nutrition in poultry and swine. Asian-Australasian J Anim Sci 2010, 23:1527-1534. 
12. Rath NC, Balog JM, Huff WE, Huff GR, Kulkarni GB, Tierce JF: Comparative differences in the composition and biomechanical properties of tibiae of seven- and seventy-twoweek-old male and female broiler breeder chickens. Poult Sci 1999, 78:1232-1239.

13. Silva RAM, Pacheco GD, Vinokurovas SL, Oliveira ER, Gavioli DF, Lorazo AP, Agostini PS, Bridi AM, Silva CA: Associação de ractopamina e vitaminas antioxidantes para suínos em terminação. Cienc Rural 2015, 45:311-316.

14. Pappas AC, Zoidus EA, Surai PF, Zervas G: Selenoproteins and maternal nutrition. Comp Biochem Physiol B 2008, 151:361-372.

15. Zoidis E, Pappas AC, Georgiou CA, Komaitis E, Fegeros K: Selenium affects the expression of GPx4 and catalase in the liver of chicken. Comp Bioch Physiol B 155:294-300.

16. Lang C, Murgia C, Leong M, Tan LW, Perozzi G, Knight D, Ruffin R, Zalewski P: Antiinflammatory effects of zinc and alterations in zinc transporter mRNA in mouse models of allergic inflammation. Am J Physiol Lung Cell Mol Physiol 2007, 292:577-584.

17. Hu CH, Qian ZC, Song J: Effects of zinc oxide-montmorillonite hybrid on growth performance, intestinal structure, and function of broiler chicken. Poult Sci 2013, 92:143150.

18. Roselli M, Finamore A, Garaguso I, Britti MS, Mengheri E: Zinc oxide protects cultured enterocytes from the damage induced by Escherichia coli. J Nutr 2003, 133:4077-4082.

19. Bischoff S: Open Research Computation: Intestinal permeability-a new target for disease prevention and therapy. [https://bmcgastroenterol.biomedcentral.com/track/ pdf/10.1186/s12876-014-0189-7?site=bmcgastroenterol.biomedcentral.com]

20. Ulluwishewa D, Anderson RC, McNabb WC, Moughan PJ, Wells JM, Roy NC: Regulation of tight junction permeability by intestinal bacteria and dietary components. J Nutri 2011, 141:769-776.

21. Suzuki T: Regulation of intestinal epithelial permeability by tight junctions. Cell Mol Life Sci 2013, 70:631-659.

22. Sakomura NK, Rostagno HS. In: Métodos de pesquisa em nutrição de monogástricos: Planejamento dos experimentos com monogástricos. Jaboticabal: Funep; 2007, 17-35.

23. Kisielinski K, Willis S, Prescher A, Klosterhalfen B, Schumpelick V: A simple new method to calculate small intestine absorptive surface in the rat. Clin Exp Med 2002, 2:131-135.

24. SAS Institute Inc.: Software and services: system for Windows, version 8.0, software Cary 2002.

25. Funari Júnior P, Albuquerque R, Alves FR, Murarolli MDA, Trindade Neto MA, Silva EM: Diferentes fontes e níveis de selênio sobre o desempenho de frangos de corte. Braz J Vet Res Anim Sci 2010, 47:380-384.

26. Zhao J, Shirley RB, Vazquez-Anon M, Dibner JJ, Richards JD, Fisher P, Hampton T, Christensen KD, Allard JP, Giesen AF: Effects of chelated trace minerals on growth performance, breast meat yield, and footpad health in commercial meat broilers. J Appl Poult Res 2010, 19:365-372.

27. Manangi MK, Vazquez-Anon M, Richards JD, Carter S, Buresh RE, Christensen KD: Impact of feeding lower levels of chelated trace minerals versus industry levels of inorganic trace minerals on broiler performance, yield, footpad health, and litter mineral concentration. J Appl Poult Res 2012, 21:881-890.

28. Yogesh K, Deo C, Shrivastava HP, Mandal AB, Wadhwa A, Singh I: Growth performance, carcass yield, and immune competence of broiler chickens as influenced by dietary supplemental zinc sources and levels. Agric Res 2013, 2:270-274. 
29. Carvalho GB, Lopes JB, Silva SRG, Dourado IRB, Miranda DFH, Costa FAL: Desempenho, morfometria duodenal e histopatologia do fígado de frangos de corte alimentados com dietas contendo diferentes níveis de selênio orgânico em condições de estresse calórico. Rev Bras Saúde Prod Anim 2015, 16:365-376.

30. Zuidhof MJ, Schneider BL, Carney VL, Korver DR, Robinson FE: Growth, efficiency, and yield of commercial broilers from 1957, 1978, and 2005. Poult Sci 2014, 93:2970-2982.

31. Bao YM, Choct M, Iji P, Bruerton K: Trace mineral interactions in broiler chicken diets. Br Poult Sci 2010, 51:109-117.

32. Gheisari AA, Rahimi-Fathkoohi A, Toghyani M, Gheisari MM: Effects of organic chelates of zinc, manganese and copper in comparison to their inorganic sources on performance of broiler chickens. J Anim Plant Sci 2010, 6:630-636.

33. Bao YM, Choct M, Iji PA, Bruerton K: Effect of organically complexed copper, iron, manganese, and zinc on broiler performance, mineral excretion, and accumulation in tissues. J Appl Poult Res 2007, 16:448-455.

34. Jeurissen SHM, Lewis F, Klis JDV, Mroz Z, Rebel JMJ, Huurne AAHM: Parameters and Techniques to Determine Intestinal Health of Poultry as Constituted by Immunity, Integrity and Functionality. Curr Issues Intest Microbiol 2002, 3:1-14.

35. Viola ES, Vieira SL: Suplementação de acidificantes orgânicos e inorgânicos em dietas para frangos de corte: desempenho zootécnico e morfologia intestinal. R Bras Zootec 2007, 36:1097-1104.

36. Jayaraman S, Thangavel G, Kurian H, Mani R, Mukkalil R, Chirakkal H: Bacillus subtilis PB6 improves intestinal health of broiler chickens challenged with Clostridium perfringensinduced necrotic enteritis. Poult Sci 2013, 92:370-374.

37. Silva MAD, Pessotti BMDS, Zanini SF, Colnago GL, Nunes LDC, Rodrigues MRA, Ferreira L: Óleo essencial de aroeira-vermelha como aditivo na ração de frangos de corte. Cienc. Rural 2011, 41:676-681.

38. Boleli IC, Maiorka A, Macari M: Estrutura funcional do trato digestório. In: MACARI, M.; FURLAN, R.L.; GONZALES, E. Fisiologia aviária aplicada a frangos de corte. Jaboticabal, São Paulo: Funep; 2002, 75-95.

39. Maiorka A, Santin E, Dahlke F, Boleli IC, Furlan RL, Macari M: Posthatching water and feed deprivation affect the gastrointestinal tract and intestinal mucosa development of broiler chicks. J Appl Poult Res 2003, 12:483-492.

40. Tan J, Applegate TJ, Liu S, Guo Y, Eicher SD: Supplemental dietery L-arginine attenuates intestinal mucosal disruption during a coccidial vaccine challenge in broiler chickens. $\mathrm{Br}$ JNutr 2014, 112:1098-1109. 


\title{
MINERALNI SUPLEMENTI: EFEKTI NA INTEGRITET KOSTIJU I MORFOLOGIJU INTESTINALNOG TRAKTA BROJLERA VEŠTAČKI INFICIRANIH SA EIMERIA SP
}

\author{
FERNANDES MÜLLER Inês Jovanir, RIBEIRO VISSOTTOO Mayra, CARDOSO \\ BITTENCOURT Letícia, RIFFEL Thais Eliana, LIMA KAISER Fernanda, PALMA \\ CASTRO Sabrina, HERMES Gustavo Rafael
}

Cilj studije je bio da se obavi evaluacija efekta suplementacije organskim mineralnim materijama na performanse produktivnosti i kvalitet kostiju brojlera uzrasta od jedan do 21 dan kao i evaluacija zdravstvenog stanja intestinalnog trakta u situaciji kada su brojleri veštački zaraženi sa Eimeria sp, u starosti od 21 i 28 dana. Dizajn ogleda je bio potpuno slučajan izbor grupa, sa dva tretmana mineralima i to u formi sulfata $\mathrm{i} u$ formi Carbo-Amino-Fosfo-Helata (CAPC) pri čemu je ukupno 900 brojlera muškog pola podeljeno na 9 ponavljanja i 18 eksperimentalnih grupa sa po 50 ptica. Šest stotina i četrdeset brojlera su u starosti od 21 dan, prebačeni u eksperimentalne kaveze posle čega su slučajnim izborom podeljeni u grupe tako što su formirane tretirane grupe $2 \times 2$ (mineralli u formi sulfata i CAPC x sa i bez veštačke infekcije intestinalnog trakta) pri čemu je dobijeno 4 tretmana sa 16 ponavljanja i to po 10 ptica. Istog dana kada je obavljena veštačka infekcija, ptice iz grupe koja je veštački inficirana bile su vakcinisane komercijalnom anti-kokcidija vakcinom koja je u sebi sadržavala i Eimeria spp imunogen. Posle 7 dana, suplementacija sa CAPC mineralima imala je za posledicu veću telesnu masu $(<0,05)$ i bolju konverziju hrane u odnosu na grupu koja je primala neorganske minerale. Deponovanje minerala koje je praćeno u tibiji brojlera, nije bilo pod uticajem ( $\mathrm{p}>0,05)$ izvora minerala osim u slučaju bakra i mangana, kod kojih je uočena veća $(\mathrm{p}<0,05)$ depozicija u kostima kod ptica koje su primile minerale iz neorganskog izvora. Uočena je veća dužina i prečnik intestinalnih resica kao i povećanje odnosa resice:kripte, a kao odgovor na destrukciju usled suplementacije CAPC u poređenju sa primenom neorganskih minerala. 